\title{
Dynamically enhanced membrane foaming
}

\section{Doctoral Thesis}

Author(s):

Müller-Fischer, Nadina

Publication date:

2007

Permanent link:

https://doi.org/10.3929/ethz-a-005331832

Rights / license:

In Copyright - Non-Commercial Use Permitted

Originally published in:

Food process engineering 28 


\title{
Dynamically Enhanced Membrane Foaming
}

\author{
A dissertation submitted to the \\ Swiss Federal Institute of Technology Zurich \\ for the degree of \\ Doctor of Sciences \\ presented by \\ Nadina Müller-Fischer \\ Dipl. Lm.-Ing. ETH, ETH Zürich \\ born November 18, 1977 \\ citizen of Switzerland \\ accepted on the recommendation of \\ Prof. Dr.-Ing. E.J. Windhab, examiner \\ Dr. Martin E. Leser, co-examiner
}




\section{Abstract}

Foamed food products like ice cream, chocolate mousse, fresh cheese or bakery products are increasingly popular due to their soft and creamy sensory properties. The perception, stability and flow behavior of food foams strongly depend on gas fraction and bubble size distribution. Ideally, foams contain smallest possible gas bubbles of equal size. If the gas bubbles are small enough, they can not be distinguished from fat particles in the mouth. Hence, fat can be replaced by gas, leading to a fat-free yet creamy product. A narrow size distribution slows destabilization mechanisms, and thus, the amount of stabilizers can be reduced or the shelf life prolonged. In numerous life science related application areas foams are manufactured using rotor-stator gas dispersing devices where gas is added to the fluid mix and dispersed by the flow forces (shear, elongation, inertia) acting in the whipping head. Improvements with regards to foam characteristics are often achieved by altering the ingredients composition but maintaining the same processing conditions. Contrary to this approach, the focus of this work was to understand and develop a new foaming process in which smaller and more narrowly distributed bubbles can be achieved without changing the recipe.

Fundamental insight into the mechanisms of bubble breakup in simple shear was sought. Experiments in a parallel band apparatus and a transparent concentric cylinder setup allowed the observation of bubble deformation and breakup, respectively. To date, no data regarding bubble breakup are found in literature. It was shown that no clear distinction between tip breakup and fracture can be made for bubbles. Critical Capillary numbers for bubble breakup between about 29 and 45 were found for viscosity ratios between $3.1 \cdot 10^{-7}$ and $6.7 \cdot 10^{-8}$, respectively.

Another aim of this study was to determine the impact of reduced static pressure acting during the foaming process on the resulting foam microstructure. Since the gaseous disperse phase is compressible, static pressure plays a major role in foam production. Commonly, industrial foam production takes place in a pressure range of 2 - 4 bar absolute in order to reduce the effective gas volume fraction in the whipping device. However, the bubbles expand as soon as they are exposed to atmospheric pressure. To investigate the inverse effect, namely a bubble shrinkage during adaptation to atmospheric pressure, the static pressure in the whipping head was reduced to partial vacuum of 0.6 bar. The comparison of pressures between 0.6 and 4.0 bar, however, showed that best foaming results are achieved at atmospheric pressure compared to both increased and reduced static pressure. For foams whipped at increased pressure, the bubbles grew during expansion to 
atmospheric condition while at reduced pressure coalescence probability was increased in the rotor-stator whipping device as a consequence of the enlarged gas volume fraction.

Furthermore, new types of foaming devices using either (i) a rotating membrane (ROME) or (ii) dynamically enhanced static membrane (DESM) were developed and characterized. The devices consist of two concentric cylinders, one forming the membrane: (i) rotor = membrane, (ii) membrane attached to housing. In (i) and (ii), the inner cylinder rotates with circumferential velocities up to $30 \mathrm{~m} / \mathrm{s}$. Air is pressed through the membrane into the narrow annular gap through which the continuous fluid phase passes. Bubbles are detached from the rotating membrane surface and further dispersed in the narrow annular gap due to the high acting shear stresses. Contrary to aeration with conventional non-rotating membrane devices, the shear stress is controlled by the circumferential velocity of the inner cylinder and is, thus, de-coupled from the volume throughput rate of the continuous fluid phase. The impact of shear rate, gas volume fraction, gap size, type of membrane, residence time and volumetric energy input was quantified for membranes of various types and pore sizes.

Foams produced with the newly developed devices were systematically compared to those whipped with an industrially commonly used rotor-stator device. The new ROME and DESM devices were shown to produce bubbles of about half the mean size for gas volume fractions $>0.5$ and with significantly narrower size distribution. The volumetric energy input $E_{V}$ of the new devices is about one order of magnitude lower for the dynamically enhanced membrane device as a consequence of the reduced residence time necessary to disperse the gas bubbles. The DESM device was scaled up to pilot scale, built and tested. The results of laboratory and pilot scale DESM devices were comparable with respect to foam microstructure.

In order to get detailed information on the bubble formation mechanism in the dynamically enhanced membrane foaming device, bubble detachment from a single pore of a rotating membrane was visualized and systematically observed through a transparent housing construction. Based on a balance of forces valid for a bubble at the membrane surface, a simplified model was derived which allows the estimation of the mean size of the detached bubbles as a function of the acting shear rate. Experiments and model were in good agreement.

The combination of results on bubble breakup in simple shear, on detachment of bubbles from the pore of a rotating membrane and rheological and microstructural analysis of foams showed that the detachment of small bubbles from the membrane is the dominating bubble formation process in the dynamically enhanced membrane foaming process. An additional dispersing in the narrow annular gap is of minor importance. 


\section{Zusammenfassung}

Geschäumte Lebensmittelprodukte werden aufgrund ihrer angenehmen Textur immer beliebter. Dabei gibt es neben Desserprodukten wie Schokoladenmousse oder Eiskrem auch eine grosse Vielfalt an salzigen Produkten wie Frischkäse oder Lachsmousse. In geschäumten Produkten beeinflussen der Gasanteil und die Blasengrössenverteilung das Texturempfinden im Mund massgeblich. Idealerweise enthalten Schäume möglichst kleine Blasen, da sich diese im Mundraum nicht von Fettpartikeln unterscheiden lassen. Ein gänzlich fettfreies Produkt wird so trotzdem als kremig wahrgenommen. Eine enge Blasengrössenverteilung hingegen erhöht die Stabilität des Produktes, was dazu führt, dass dieses entweder länger haltbar ist oder Zusatzstoffe wie Verdickungsmittel und Stabilisatoren reduziert werden können. Vielfach werden Schäume industriell mit Rotor-Stator Aufschlagmaschinen hergestellt. Gas wird im Aufschlagkopf in vielen Schritten durch die wirkenden Fliesskräfte (Scher-, Dehn- und Trägheitskräfte) in kleinere Blasen zerteilt. Produktverbesserungen werden oft durch eine Veränderung der Rezeptur bewirkt, während der Aufschlagprozess selten genauer betrachtet wird. Der Fokus der vorliegenden Arbeit war es hingegen, die Blasenentstehung besser zu untersuchen und einen neuen Aufschäumprozess zu entwickeln, mit dem kleinere und enger verteilte Gasblasen erzielt werden können.

In einem fundamentaleren Teil dieser Arbeit wurden Erkenntnisse zu Blasenaufbruchsmechanismen in einfacher Scherströmung gesucht. Dazu wurden Versuche in einer durchsichtigen konzentrischen Zylinder-Konstruktion durchgeführt. Es gelang, bei tiefen Viskositätsverhältnissen Blasenaufbruch zu erzielen, wozu bislang keine Veröffentlichungen existieren. Für Viskositätsverhältnisse zwischen $3.1 \cdot 10^{-7}$ und $6.7 \cdot 10^{-8}$ wurden kritische Kapillarzahlen zwischen 29 und 45 ermittelt. Es konnte zudem gezeigt werden, dass es für Blasen keinen klar erkennbaren Unterschied zwischen gesamthaftem Aufbruch und Abscheren der Blasenspitze gibt, so wie das für Emulsionstropfen bekannt ist.

Weiterhin wurde der Einfluss des statischen Druckes auf die resultierende Schaumstruktur untersucht. Da die gasförmige disperse Phase in Schäumen kompressibel ist, spielt der statische Druck während des Aufschäumprozesses eine bedeutende Rolle. In industriellen Herstellungsprozessen wird herkömmlicherweise bei absoluten Drücken zwischen 2 und 4 bar gearbeitet, um das Gasvolumen zu verkleinern. Sobald der Schaum aus der Anlage austritt und Atmosphärendruck ausgesetzt ist, wachsen die Blasen wiederum an, was für die Schaumstruktur unvorteilhaft ist. Innerhalb dieser Arbeit wurden deshalb Drücke bis hinunter zu 0.6 bar absolut un- 
tersucht, um den gegenteiligen Einfluss eines Blasenschrumpfens bei Belüftung zu beobachten und analysieren. Der Vergleich dieser Schäume zeigte, dass sowohl ein erhöhter als auch ein reduzierter statischer Druck zu negativen Veränderungen der Schaumstruktur führt und dass die Schaumproduktion bei Atmosphärendruck zu den eindeutig kleinsten mittleren Blasengrössen führt. Es konnte weiterhin gezeigt werden, dass das Blasenvolumen sich entsprechend dem idealen Gasgesetz mit dem statischen Druck ändert.

In einem weiteren Teil dieser Arbeit wurde ein neuer Aufschäumprozess entwickelt, das sogenannte dynamische Membranschäumen. Die zugehörige Maschine besteht aus zwei konzentrischen Zylindern, von denen jeweils der eine aus kompaktem Metall besteht, während der andere die Membran ist. Der innere Zylinder kann mit Umfangsgeschwindigkeiten bis zu $30 \mathrm{~m} / \mathrm{s}$ rotiert werden. Die disperse Gasphase wird durch die Membran in den engen Ringspalt gedrückt, durch den der Mix hindurchfliesst. Die an den Poren der Membran gebildeten Blasen werden dank der hohen Schubspannung frühzeitig von der Membran abgelöst und erfahren im engen Ringspalt eine weitere Dispergierung. Anders als bei einer Schaumherstellung mittels einem statischen Membranaufbau ist die wirkende Spannung vom Durchsatz entkoppelt. Der Einfluss der Scherrate, des Gasanteiles, der Spaltweite, des Membrantyps, der Verweilzeit und des volumenspezifischen Energieeintrages wurden für Membranen mit verschiedenen Porengrössen quantitativ analysiert. Die so hergestellten Schäume wurden mit Schäumen verglichen, die mit einer herkömmlichen Rotor-Stator Anlage hergestellt wurden. Es konnte gezeigt werden, dass das dynamische Membranschäumen es ermöglicht, bei einem Gasanteil $>0.5$ halb so grosse mittlere Blasengrössen mit engeren Blasengrössenverteilungen herzustellen. Der volumetrische Energieeintrag ins Produkt ist aufgrund der gleichermassen verkürzten Verweilzeit etwa eine Zehnerpotenz kleiner für Membrananlage. Die neue Membrananlage wurde in grösserem Massstab ausgelegt und gebaut. Vergleichende Versuche von Labor- und Pilotanlage zeigten, dass die resultierenden Blasengrössen praktisch identisch sind.

Ausserdem wurde der Blasenablösungsvorgang von den Poren der rotierenden Membran näher untersucht. Dazu wurde ein durchsichtiger Aussenmantel konstruiert und es wurden bei verschiedenen Drehzahlen mit einer Hochgeschwindigkeitskamera Filme aufgenommen. Die resultierenden Blasengrössen wurden analysiert und mit einem auf dem Kräftegleichgewicht basierenden Modell verglichen. Dabei wurde eine gute Übereinstimmung zwischen Modell und Visualisierungsexperiment gefunden.

Die Kombination der Resultate zu (i) Blasenaufbruch in einfacher Scherströmung, zu (ii) Blasenablösung von der Pore einer rotierenden Membran und zur rheologischen und mikrostrukturellen Analyse von Schäumen (iii) hat gezeigt, dass die Blasenablösung der dominierende Blasenbildungsvorgang im dynamischen Membranschäumprozess ist. Die weitere Dispergierung im engen Ringspalt ist von untergeordneter Bedeutung. 